\title{
Pelatihan Pidato Bahasa Inggris untuk Santri di Pondok Pesantren Nurul Qur'an Bogor
}

\author{
Ismi Adinda ${ }^{1}$, Lida Holida Mahmud ${ }^{2}$, Tryana ${ }^{3}$ \\ Universitas Pamulang \\ Korespondensi: dosen00602@unpam.ac.id ${ }^{1}$,dosen00514@unpam.ac.id², \\ dosen00420@unpam.ac.id ${ }^{3}$
}

\begin{abstract}
Based on observations, Community Service Activities (PKM) at Pondok Pesantren Nurul Quran aimed to improve students' English speaking abilities in public. This PKM applied 3 types training methods of speech from Keraf's theory (1977), persuasive which is to persuade subtly so that others feel confident about what is meant by the speaker, instructive namely to inform or preach information to the listener in the form of a proper understanding, and recreative that is fun and entertaining so that there arises a joy when listening and of course move to follow what is said by the speaker. The training also approached, mentored, gave technical speeches and direct practicd training in English, involving 50 respondents or traines from grade 10 Pondok Pesantren Nurul Qur'an. The results of this PKM activities showed that the methods provide an enhancement in students' abilities, self-confidence and self-comfort for students in speaking English in public.
\end{abstract}

Keywords: English, improving, public speech, speaking ability

\begin{abstract}
Abstrak
Berdasarkan observasi, Kegiatan Pengabdian Kepada Masyarakat (PKM) di Pondok Pesantren Nurul Qur'an bertujuan untuk meningkatkan kemampuan berbicara siswa dalam Bahasa Inggris di depan umum. PKM ini menggunakan metode pelatihan 3 jenis pidato dari teori Keraf (1977) yakni persuasif yakni membujuk secara halus agar orang lain merasa yakin terhadap apa yang dimaksud oleh si pembicara, instruktif yakni memberitahukan atau mengabarkan suatu informasi kepada pendengar berupa suatu pengertian yang tepat, dan rekreatif yakni menyenangkan dan menghibur sehingga muncul suatu kegembiraan saat mendengarkan dan tentunya tergugah untuk mengikuti apa yang diucapkan oleh pembicara. Pelatihan ini juga melakukan pendekatan, pendampingan, pelatihan teknik berpidato serta praktek langsung dengan menggunakan Bahasa Inggris yang melibatkan responden atau peserta pelatihan sebanyak 50 siswa yang berasal dari kelas 10 Pondok Pesantren Nurul Qur'an. Dari hasil kegiatan PKM ini ditemukan bahwa metode, memberikan peningkatan terhadap kemampuan, percaya diri dan kenyamanan diri siswa dalam berbicara Bahasa Inggris di depan umum.
\end{abstract}

Kata Kunci: Bahasa Inggris, berbicara, kemampuan, meningkatkan, pidato publik 


\section{A. Pendahuluan}

Meskipun pemerintah Indonesia telah berkomitmen menargetkan mahasiswa dan dosen sebagai agent of change bagi masyarakat, tetapi masih banyak persoalan di masyarakat, termasuk di dalamnya isu-isu masih lemahnya daya saing masyarakat Indonesia di mata dunia dikarenakan masalah kualitas pendidikan formal dan non formal masyarakat itu sendiri.

Untuk menyikapi masalah tersebut pemerintah melalui Pendidikan Tinggi telah membangun komitmen melalui Tri Dharma Perguruan Tinggi dengan salah satu amanatnya yang harus diemban oleh seluruh perguruan tinggi di Indoneisa yaitu Pengabdian Masyarakat. Tujuan pengabdian masyarakat ini adalah untuk menerapkan ilmu dan pengetahuan yang didapat dari kegiatan akademik kepada masyarakat agar masyarakat maju dan sejahtera.

Manusia sebagai mahluk sosial tidak akan bisa dipisahkan dari bahasa. Bahasa merupakan alat komunikasi manusia dengan manusia lainnya yang kemudian membentuk suatu peradaban. Bahasa menjadi jendela dunia bagi manusia. Salah satu jendela dunia tersebut adalah Bahasa Inggris. Bahasa Inggris mendominasi seluruh aspek komunikasi dunia sehingga menjadi bahasa internasional. Suka tidak suka, di abad ini seluruh individu di dunia membutuhkan Bahasa Inggris.

Mengingat bagaimana pentingnya Bahasa Inggris tersebut dalam perkembangan global, Pemerintah Indonesia meresponnya dengan mengeluarkan Peraturan Pemerintah No 32 Tahun 2013 yang mewajibkan Bahasa Inggris sebagai muatan lokal pada tingkat pendidikan dasar sampai dengan pendidikan tinggi dengan tujuan untuk meningkatkan mutu dan daya saing bangsa.

Bahasa Inggris adalah jendela dunia. Richard (2001) dalam bukunya mengemukakan, Today English so widely taught worldwide that the purposes for which it is learned are sometimes taken for granted. Hal ini mengindikasi bahwa saat ini Bahasa Inggris diajarkan secara luas di seluruh dunia dan bagi yang mempelajarinya maka dia akan mendapatkan kemudahan.

Dari keempat keterampilan berbahasa Inggris (reading, writing, grammar dan speaking), kemampuan yang paling penting adalah berbicara atau speaking. Berikut ini pengertian berbicara menurut para ahli:

"Berbicara merupakan alat komunikasi yang umum dalam masyarakat. Dalam hal ini berbicara secara umum dapat diartikan suatu penyampaian maksud yang bisa berupa gagasan, pikiran, isi hati seseorang kepada orang lain” (Slamet, 2007) .

"Berbicara adalah keterampilan menyampaikan pesan melalui bahasa lisan" (Tarigan,1990).

"Berbicara adalah suatu keterampilan berbahasa yang berkembang pada kehidupan anak, yang hanya didahului oleh keterampilan menyimak, dan pada masa tersebutlah kemampuan berbicara atau berujar dipelajari” (Guntur, 2013).

Pernyataan para ahli tersebut mengkonfirmasi bahwa berbicara merupakan puncak akumulasi kemampuan suatu bahasa. Hal ini mengindikasi bahwa apabila seseorang menguasai speaking berarti menguasai Bahasa Inggris aktif. Celce and Murcia menyebutkan bahwa "speaking is one of communicative skills that 
indicates that a learner can master English language actively because speech is the most basic means of human communication" (2001, p. 103).

Pembelajaran berbicara Bahasa Inggris erat kaitannya dengan tujuan didirikannya Pondok Pesantren Nurul Qur'an. Tujuan pendidikan di lembaga tersebut adalah mencetak dai/hafidz yang berkiprah di masyarakat baik di tingkat lokal maupun internasional. "Berkiprah di masyarakat" artinya para lulusan nantinya bukan hanya berbaur dengan masyarakat tetapi juga berperan aktif dalam menyebarkan ilmu agama yang mereka miliki. Tentunya hal ini membutuhkan kemampuan berbicara di depan umum.

Pidato merupakan tehnik mengungkapkan pikiran dalam bentuk kata- kata yang ditujukan kepada orang banyak (Depdikbud, 1990, p. 681). Pidato adalah teknik pemakaian kata-kata atau bahasa secara efektif yang bisa diartikan sebagai keterampilan atau kemahiran dalam memilih kata yang dapat mempengaruhi komunikan tersebut (Syam, 2006, p. 7). Berpidato adalah menyampaikan dan menanamkan pikiran, informasi atau gagasan dari pembicara kepada khalayak ramai dan bermaksud meyakinkan pendengarnya (Arsjad, 1988, p. 53).

Salah satu program utama di Pondok Pesantren Nurul Qur'an adalah tafsir Alquran, di mana santri harus mampu menghafal dan memahami kandungan Alquran dengan dilandasi dan dikuatkan oleh hadist-hadist Rosulullah serta pendapat para ulama. Tentu saja program ini membutuhkan banyak referensi terkait, beberapa diantaranya tersedia dalam Bahasa Inggris.

Program ini tidak hanya terhenti sampai level memahami Alquran tetapi juga mentargetkan santri untuk mampu menyampaikan isi kandungan Alquran tersebut kepada masyarakat, baik pada level nasional maupun internasional, contohnya dengan menjadi khotib Jumat atau menjadi qori/ qoriah serta mufasir/ mufasiroh yang mumpuni yang nantinya dapat dimanfaatkan baik di kancah nasional ataupun internasional yang tentunya menggunakan Bahasa Inggris sebagai bahasa global.

Dengan kata lain, program andalan pesantren ini mewajibkan santri suka ataupun tidak suka harus memiliki kemampuan bahasa Inggris sebagai bahasa pengantar dalam meraih tujuan utama mereka yaitu menjadi dai/ qori/ mufasir dan mufasiroh yang notabene akan terjun langsung berhadapan dan akan sering berbicara dengan khalayak umum/ publik.

Berdasarkan observasi, proses pembelajaran Bahasa Inggris di Pondok Pesantren Nurul Qur'an diselenggarakan sesuai dengan kurikulum nasional, namun buku- buku yang dipakai untuk bahan ajar Bahasa Inggris oleh pengajar merupakan buku turun temurun dari pengajar sebelumnya tanpa adanya modulmodul pendukung lainnya. Begitupun dengan lokasi pesantren yang jauh dari perkotaan yang dapat ditempuh hampir sekitar dua jam perjalanan menggunakan motor, tidak memiliki sinyal internet yang cukup bagus dalam mengakses internet, serta minimnya sarana penunjang seperti komputer dan juga laboratorium bahasa, membuat penyelenggaran pendidikan khususnya Bahasa Inggris berlangsung hanya mengandalkan sumber sumber yang terbatas dan sulit untuk mengembangkan dan mengakses ilmu terkini.

Peraturan pesantren yang tidak memperbolehkan telepon genggam dapat membatasi akses internet dan membuat siswa terpaku pada metode pembelajaran 
lampau. Di pesantren tersebut belum tersedia perpustakaan sebagai sumber buku dan referensi terkini bagi guru dan siswa. Tidak adanya laboratorium bahasa membuat pembelajaran listening hanya berlangsung di kelas menggunakan perekam suara atau langsung melalui suara pengajar. Dengan kondisi pesantren tersebut, proses pembelajaran Bahasa Inggris lebih berpusat pada guru/teachercentred.

Untuk mencapai keberhasilan menguasai kemampuan berbicara Bahasa Inggris, tentunya peran guru adalah hal yang utama. Guru diharapkan tidak menggunakan metode yang monoton dalam mengajar, karena akan membuat pelajar menjadi malas, bosan, jenuh, bahkan berisik. Akan tetapi data survei dan observasi di target sasaran mengindikasi hal sebaliknya.

Pada saat survei di pesantren tersebut, guru Bahasa Inggris bertanya kepada siswa untuk dijawab tanpa ditunjuk tentang unforgetable moment yang siswa miliki, hasilnya tidak ada satu siswa pun yang angkat tangan untuk menjawab pertanyaan guru. Kondisi yang terjadi saat itu siswa berisik, berbisikbisik dengan teman-temannya tanpa ada yang mau menjawab.

Survei lain yang dilakukan secara bersaman kepada guru, ditemukan bahwa guru sering menggunakan metode percakapan secara berpasangan, untuk memperaktekan percakapan pada teks bahasa Inggris yang telah dicatat. Hasil wawancara dengan siswa menunjukan bahwa metode seperti ini membuat pelajar menjadi malas, bosan, jenuh, bahkan berisik. Kegiatan ini hanya melatih kemampuan pelafalannya saja, tidak dengan kemampuan linguistik ataupun rasa percaya diri, karena siswa atau siswi maju ke depan untuk praktek ditemani oleh pasangan.

Berdasarkan hasil observasi dan wawancara dengan guru Bahasa Inggris dan siswa Pesantren Nurul Qur'an, dapat disimpulkan bahwa terdapat beberapa permasalahan yang menghambat siswa dalam meningkatkan kemampuan berbahasa Inggris khususnya kemampuan berbicara Bahasa Inggris di depan umum. Hal ini karena kurang menariknya teknik/metode pembelajaran Bahasa Inggris khususnya keterampilan speaking/ berbicara, kurangnya media pembelajaran yang menunjang keahlian berbicara Bahasa Inggris, kurangnya kepercayaan diri para santri/siswa untuk tampil berbahasa Inggris di depan publik serta kurangnya penguasaan kosa-kata dan tata bahasa grammar Bahasa Inggris oleh santri, serta kurangnya pengetahuan tentang tips dan tehnik dalam berbicara Bahasa Inggris di depan publik.

Berdasarkan permasalahan tersebut, diperlukan suatu metode pelatihan berbicara Bahasa Inggris yang menarik yang bisa mendorong siswa untuk lebih aktif berbicara di depan umum. Berdasarkan permasalahan tersebut, diperlukan suatu metode pelatihan berbicara Bahasa Inggris yang menarik yang bisa mendorong siswa untuk lebih aktif berbicara didepan umum.

Tujuan yang ingin dicapai dalam pengabdian masyarakat ini adalah mengamalkan ilmu agama dan pengetahuan yang didapat dari kegiatan akademik, serta dapat meningkatkan kemampuan para siswa/ santri Pondok Pesantren Nurul Qur'an terhadap jenis-jenis berbicara seperti yang dikatakan Keraf (1977), yakni berbicara secara persuasif, instruktif dan rekreatif dengan menggunakan Bahasa Inggris kepada publik baik lokal maupun internasional. 
Bagi para siswa Pondok Pesantren Nurul Qur'an, pelatihan berbicara Bahasa Inggris di depan umum melalui metode pidato Bahasa Inggris ini memberikan rasa nyaman dan percaya diri pada siswa sehingga berdampak positif dalam peningkatan kompetensi berbicara siswa di depan umum dengan menggunakan Bahasa Inggris. Dampak positif ini diharapkan pembelajaran speaking. Bahasa Inggris tidak dianggap lagi suatu momok yang menakutkan tetapi menyenangkan sehingga kemampuan Bahasa Inggris siswa dapat meningkat. Bagi para civitas akademika dan dosen Prodi Sastra Inggris, pengabdian masyarakat ini dapat dijadikan sebagai wahana untuk mengamalkan ilmu serta sebagai wujud dari pengabdian masyarakat yang merupakan bagian dari Tri Dharma Perguruan Tinggi.

\section{B. Pelaksanaan dan Metode}

Kegiatan Pengabdian Masyarakat "Pelatihan Pidato Bahasa Inggris untuk Santri" berlangsung di Pondok Pesantren Nurul Qur'an, Desa Ciseeng, Kecamatan Gunung Sindur, Kabupaten Bogor. Kegiatan ini dilaksanakan pada hari Jumat sampai dengan Minggu, tanggal 8 s.d 10 November 2019.

Metode Kegiatan Pengabdian Masyarakat "Pelatihan Pidato Bahasa Inggris untuk Santri di Pondok Pesantren Nurul Qur'an Bogor" terbagi menjadi 3 tahap sebagai berikut: Tahap ini dimulai dengan observasi dan survei yang dilakukan pada bulan September.

Hasil survey dan observasi kemudian dilanjutkan dengan pengajuan proposal oleh Tim Dosen melalui LPPM. Dengan disetujuinya proposal pengabdian masyarakat yang diajukan Dosen/LPPM Universitas Pamulang di Pondok Pesantren Nurul Qur'an Gunung Sindur, Bogor, maka kami menyampaikan kepada Rektor Universitas Pamulang untuk menindaklanjuti acara tersebut sampai menunggu waktu pelaksanaan yang ditentukan pihak Madarasah Aliyah Nurul Quran.

Dari laporan kami, Rektor melalui LPPM selanjutnya menindaklanjuti dengan menugaskan kami (dosen) untuk segera mempersiapkan diri dengan berbagai materi berhubungan dengan pembelajaran Pidato Bahasa Inggris berbicara di depan umum bagi siswa Pondok Pesantren Nurul Qur'an.

Pelaksanaan kegiatan pelatihan berlangsung pada tanggal 8 s.d 10 November, hari Jumat pukul 13.00 s.d 16.00, sedangkan hari Sabtu dan Minggu berlangsung pada pukul 09.00 s.d 15.00 .

Rincian acara pelaksanaan kegiatan pengabdian masyarakat di Pondok Pesantren Nurul Qur'an, Bogor adalah sebagai berikut:

Hari Jumat:

1. Pembukaan oleh Pembawa Acara pukul 13.00 WIB

2. Sambutan

- Pengurus Pondok Pesantren Nurul Qur'an

- Ketua Panitia Kegiatan Pengabdian kepada Masyarakat

3. Brainstrorming dan sharing pengalaman antara dosen, mahasiswa dan siswa (Pukul 13.30 WIB s.d 15.15 WIB)

4. Ice breaking dengan Vocabulary Game untuk para santri (15.30 WIB 15.55 WIB) 


\section{Penutup/Pembacaan Doa (16.00 WIB)}

Hari Sabtu

1. Penyampaian Materi Pidato Bahasa Inggris oleh Dosen (09.00 WIB)

2. Penyampain Trik Berpidato Bahasa Inggris oleh Mahasiswa (10.30 WIB s.d 12.00 WIB)

3. Praktek/Latihan Berpidato oleh Siswa (13.00 WIB s.d 14.30 WIB)

4. Ice breaker dengan Game Vocabulary para Santri (15.30 WIB -15.55 WIB)

5. Penutup/Pembacaan Doa (16.00 WIB)

Hari Minggu

1. Lomba Pidato (09.00-14.00 WIB)

2. Ice Breaker dengan Game Quick Spelling (14.00 WIB)

3. Pengumuman Lomba Pidato dan Lomba Permainan (15.15 WIB)

4. Baca Doa dan Penutupan (15.30 WIB).

Materi pelatihan pada tahap ini dilakukan pelatihan yang mengarah pada tips berbicara lancar dalam berpidato berbahasa Inggris melalui metode speech Khayyirah, 2013:44):

1. Impromptu (improvisasi)

2. Extemporaneous (menyiapkan terlebih dahulu garis garis besar konsep pidato yang akan diberikan)

3. Manuscript (berdasarkan script)

4. Memorize (Mengingat)

Setelah pelaksanaan kegiatan, dilanjutkan dengan penyusunan laporan dan jurnal Pengabdian kepada Masyarakat baik secara soft copy maupun hard copy. Tujuan pelaporan dan jurnal adalah sebagai hasil luaran PKM disamping sebagai dasar rekomendasi bagi pelaksanaan PKM selanjutnya.

\section{Hasil dan Pembahasan}

Pelaksanaan Kegiatan Pengabdian Masyarakat yang dilaksanakan oleh Tim PKM Program Studi Bahasa Inggris melalui LPPM UNPAM yang mengusung tema "Pelatihan Pidato Bahasa Inggris untuk Santri di Pondok Pesantren Nurul Qur'an Bogor" telah dilaksanakan secara lancar pada tanggal 8 s.d 10 November 2019.

Dari pelatihan pidato Bahasa Inggris ini memperlihatkan hasil yang signifikan terhadap peningkatan kemampuan berbicara siswa dalam berbicara Bahasa Inggris di depan umum. Seperti pernyataan Keraf (1977) bahwa jenis pidato ada tiga yaitu pidato persuasif, persuasif dan rekreatif.

Setelah diadakan pelatihan para santri dapat menyampaikan pidato secara persuasif yakni membujuk secara halus agar orang lain merasa yakin terhadap apa yang dimaksud oleh si pembicara dan menghimbau untuk melakukan sesuatu yang bermanfaat bagi kehidupan bermasyarakat dan beragama. Santri dapat menyampaikan pidato secara instruktif yakni memberitahukan atau mengabarkan suatu informasi kepada pendengar berupa suatu pengertian yang tepat. Santri dapat menyampaikan pidato secara rekreatif yakni menyenangkan dan menghibur sehingga muncul suatu kegembiraan saat mendengarkan dan tentunya tergugah untuk mengikuti apa yang diucapkan oleh pembicara. 
Tumbuhnya rasa aman dan menyenangkan pada diri siswa Pondok Pesantren Nurul Qur'an. Hal ini tergambar jelas dari mulai awal kegiatan ketika sebelum tahap brainstroming, seluruh siswa tidak ada yang berani maju ke depan untuk menunjukan kemampuan berbicara dalam Bahasa Inggris. Hal ini terlihat berbeda ketika tahapan pelatihan selesai diberikan banyak diantara siswa tanpa merasa gugup dan tanpa terbebani untuk maju secara sukarela ke depan tanpa ditunjuk untuk praktek berpidato di depan umum.

Meningkatnya kosakata/ vocabulary bahasa Inggris siswa sehingga bisa melancarkan kemampuan berbicara Bahasa Inggris. Hal ini dapat terlihat pada saat mereka berpidato, banyak kosakata Bahasa Inggris yang baru yang dihasilkan sehingga memperlancar mereka ketika berbicara.

Hasil yang diperoleh dari pelatihan ini tidak terlepas dari pendekatan yang dilakukan yaitu pendampingan, pelatihan dan praktek. Secara umum menunjukan bahwa pendekatan yang dilakukan dalam pelatihan memberikan pengaruh yang baik dalam peningkatan kemampuan berbicara Bahasa Inggris di depan umum.

Pengaruh dari pendekatan yang dilakukan pada pelatihan ini seperti Pendampingan, pada pendampingan ini dilakukan brainstorming untuk membuka mindset siswa akan pentingnya berbicara dalam Bahasa Inggris di depan umum. Siswa dimotivasi memilih dan membaca kosa kata baru agar memperkaya kosakata mereka untuk dipergunakan pada saat berbicara.

Selain itu dalam tahap ini diberikan sharing pengalaman dari kakak mahasiswa dan dosen. Hidayanto (2013) menjelaskan bahwa model adalah suatu hal yang ingin ditiru, sama ketika kita membaca biografi kesuksesan seseorang, maka secara reflek kita ingin meniru orang yang sukses tersebut, mencari tahu bagaimana caranya dia menjadi sukses dan mencari tahu bagaimana cara dia bisa menghadapi persoalan persoalan yang dihadapi. Dari pendekatan sharing pengalaman dari para mahasiswa mendorong siswa melakukan hal dan teknik yang sama dengan apa yang disampaikan dari pengalaman inspiratif tersebut.

Pada tahap pelatihan yang mengarah pada tips dan triks berbicara lancar dalam berpidato Bahasa Inggris melalui metode speech yakni impromptu (improvisasi), extemporaneous menyiapkan terlebih dahulu garis garis besar konsep pidato yang akan diberikan), manuscript (berdasarkan script), memorized (mengingat)

Pemberian materi dengan menggambarkan kelebihan dan kekurangan dari masing masing metode speech diatas memberikan pilihan bagi siswa untuk bagaimana mereka berbicara dengan teknik yang mereka anggap nyaman. Di samping itu materi tentang cara mempersiapkan pidato dari masing masing metode speecch / pidato memberi ruang lebih kepada siswa untuk lebih merancang dan mengorganisir pesan yang akan disampaikan kepada audience, seperti yang Sulistiyowati (n.d., p. 71) sampaikan to communicate effectively, we should organize the massage that we want to convey through communicate clearly.

Tahap praktek, practice makes perfect adalah ungkapan yang paling tepat untuk mengasah kemampuan berbicara Bahasa Inggris di depan umum. Setelah dilakukan pendampingan dan pelatihan, siswa melakukan praktik langsung berpidato dalam Bahasa Inggris. Praktek pertama dilakukan secara volunteer 
respon yang didapat hampir semua siswa mengajukan diri untuk maju ke depan berpidato. Akan tetapi karena keterbatasan waktu, diberikan kesempatan hanya pada 3 orang siswa. Praktek ke dua dilakukan pada lomba berpidato dengan respon seluruh siswa secara bergiliran menunjukan kemampuan berbahasa Inggris mereka. Dari proses praktik ini menunjukan bahwa pendekatan pendampingan dan pelatihan memberikan respon positif pada kepercayaan diri siswa sehingga memotivasi mereka untuk terus terlibat dalam upaya peningkatan kemampuan berbahasa Inggris.

\section{Penutup}

\section{Simpulan}

1. PKM di Pondok Pesantren Nurul Qur'an berhasil meningkatkan kepercayaan diri dan kemampuan berbicara Bahasa Inggris pada hampir semua siswa kelas 10 .

2. PKM ini menggunakan metode pelatihan 3 jenis pidato dari teori Keraf (1977) yakni persuasif, instruktif dan rekreatif.

3. PKM ini menggunakan teknik berbicara lancar dalam berpidato Bahasa Inggris melalui metode pidato yakni impromptu (improvisasi), extemporaneous(menyiapkan terlebih dahulu garis garis besar konsep pidato yang akan diberikan), manuscript (berdasarkanscript),memorize (mengingat).

\section{Saran}

1. Untuk pelatihan berbicara di depan umum agar pesan si pembicara dapat disampaikan kepada pendengar dengan baik, hendaknya menggunakan 3 jenis berpidato dari Keraf (1977), yaitu persuasif, instruktif, dan rekreatif.

2. Untuk meningkatkan kelancaran berbicara Bahasa Inggris di depan umum, dapat menggunakan metode: impromptu (improvisasi), extemporaneous (menyiapkan terlebih dahulu garis garis besar konsep pidato yang akan diberikan), manuscript (berdasarkan skrip), memorize (mengingat).

3. Sekolah atau pesantren sebaiknya menyediakan fasilitas seperti komputer, layanan internet serta buku- buku terbaru yang dapat mengembangkan dan meningkatkan ilmu pengetahuan serta kemampuan siswa dalam berbicara Bahasa Inggris.

\section{Ucapan Terima Kasih}

1. Terima kasih yang sebesar- besarnya kepada Allah SWT, Yang telah memberikan kesehatan dan ridho-Nya sehingga kami dapat melaksanakan PKM ini dengan baik dan lancar.

2. Terimakasih kepada UNPAM dan LPPM UNPAM yang menyediakan fasilitas dan kesempatan sehingga kami dapat melaksanakan PKM ini dengan baik, lancar dan terarah.

3. Terima kasih kepada pihak Pondok Pesantren Nurul Qur'an, yang telah mengizinkan dan memberikan kami kesempatan untuk melaksanakan PKM di Pondok Pesantren Nurul Qur'an. 
http://openjournal.unpam.ac.id/index.php/ACB/issue/view/605/showToc

\section{DAFTAR PUSTAKA}

Abdurrachman, O. (1993). Dasar-dasar public relations. Bandung: Citra Aditya Bakti.

Aqib, Z. (2010). Profesioanalisme guru dalam pembelajaran. Surabaya: Percetakan Insan Cendekia.

Arsyad, A. (2011). Media pembelajaran. Jakarta: PT. Raja Grafindo Persada.

Asra, M. (2012). Metode pembelajaran. Bandung: CV. Wacana Prima.

Celce \& Murce.(Ed). (2001). Teaching english as a second or foreign language. Third Edition.USE: Henley \& Heinley.

Dalman, M. (2017). Keterampilan membaca. Depok: PT Rajagrafindo Perkasa.

Hakim, R. (2004). Teknik, pedoman dan seni berpidato. Surabaya: Indah.

Hamalik, P. D. (2011). Proses belajar mengajar. Jakarta: PT. Bumi Aksasa.

Hamdani. (2011). Strategi belajar mengajar. Bandung: CV. Pustaka Setia.

Harmer, J. (2007). How to teach english. Eidenburgh: Pearson Longman.

Hidayanto, A. (2013). Berpikir sistem, pola berpikir untuk pemahaman masalah yang lebih baik. Yogyakarta: Leutika Prio.

Isjoni. (2010). Keterampilan berbicara dan konsep dasar berbicara. Bandung: Alfabeta.

Iskandarwassid, M. (2011). Strategi pembelajaran bahasa. Bandung: PT. Remaja Rosdakarya.

Khayyirah, B. (2013). Cara pintar berbicara cerdas di depan publik. Yogyakarta: Diva Press.

Paningrum, A. (2012). Tips trik presentasi memikat. Yogyakarta: Araska.

Rakhmat, J. (2001). Retorika modern pendekatan praktis. Bandung: PT Remaja Rosdakarya.

Richards, J. (2001). Curiculum development in languange teaching. USA: Cambridge University Press.

Rohman, M. (2013). Strategi dan desain pengembangan sistem pembelajaran. Jakarta: Prestasi Pustakaraya.

Sadiman, A.S. (2014). Media pendidikan. Jakarta: PT. Raja Grafindo Persada.

Sepahvand, H. (2014). The effect of oral reproduction of short stories on speaking skill in iranian high school students (Case study: Khorram abad, iran) International Journal of Science and Research (IJSR), 3 (7), 1847-1851

Siregar, E. (1990). Teknik Berpidato dan Menguasai Massa. Jakarta: Yayasan Mari Belajar.

Slameto, D. (2013). Belajar \& faktor-faktor yang mempengaruhi. Jakarta: Rineka Cipta. 
http://openjournal.unpam.ac.id/index.php/ACB/issue/view/605/showToc

Suilan, R. (2012). Media pembelajaran. Bandung: CV. Wacana Prima.

Sulistyowati, T. Communication strategies in the conversations between indonesian university students and a native speaker. Journal for Language and Foreign Language Learning. 1(1): 71.

Sumarna, S. H. (2013). Kumpulan naskah pidato dan mc yang paling anda butuhkan dalam segala acara. Solo: Galmas Publisher.

Suyono, M. D. (2015). Belajar dan pembelajaran. Bandung: PT. Remaja Rosdakarya.

Tarigan, G. (2013). Manajemen penelitian tindakan kelas. Jember: Insan Cendekia.

Tarigan, P. D. (2015). Membaca sebagai suatu ketrampilan berbahasa. Bandung: Angkasa Bandung.

Tarigan, P. D. (2015). Menyimak sebagai suatu ketrampilan berbahasa. Bandung: Angkasa Bandung.

Tarigan. (1983). Berbicara sebagai suatu keterampilan berbahasa. Bandung: Angkasa.

Uno, H. B. (2012). Model pembelajaran. Jakarta: Bumi Aksara.

Wisanggeni, T. (2011). 2 Jam mahir menjadi mc \&berpidato dalam bahasa indonesia.Yogyakarta: Araska 